Original Article

\title{
BERRY EXTRACTS IMPROVED INFLAMMATORY CYTOKINES, ANTIOXIDANT ENZYME AND SUPPRESSED THE GENE EXPRESSION ALTERATIONS IN DIABETIC RATS
}

\author{
FAROUK K. EL-BAZ ${ }^{1}$, WAGDY K. B. KHALIL ${ }^{2}$, HANAN F. ALY ${ }^{3}$, HODA F. BOOLES $^{2}$
}

${ }^{1}$ Plant Biochemistry Department, ${ }^{2}$ Cell Biology Department, ${ }^{3}$ Therapeutic Chemistry Department, National Research Centre (NRC), 33 El Bohouth St. (former El Tahrir st.), Dokki, Giza, Egypt

Email: fa_elbaz@hotmail.com

Received: 03 Aug 2016 Revised and Accepted: 21 Sep 2016

\begin{abstract}
Objective: The present work was conducted to evaluate the ameliorative effect of red berry (Morus rubra) and white berry (Morus alba) extracts in diabetic rats.

Methods: Inflammatory biomarkers; tumor necrosis factor- $\alpha$ (TNF- $\alpha$ ), interleukin-1 $\beta$ (IL-1 $1 \beta$ ), transforming growth factor- $\beta$ (TGF- $\beta$ ), paraoxanase 1 (PON1), gene expression of apoptosis and inflammatory related genes were carried out.

Results: Treatment of male rats with streptozotocin (STZ) to induce diabetes increased the levels of TNF- $\alpha$, IL- $1 \beta$, TGF- $\beta$, the apoptosis rates and the alterations of the pro-apoptosis (eotaxin, caspase-1, and caspase-2) and inflammation; nuclear factor kappa-light-chain-enhancer of activated B cells (NF-KB1) and allograft inflammatory factor 1 (AIF-1) related genes. While marked reduction in PON1 level was detected in STZ-induced diabetic rats. However, treatment of STZ-exposed rats with red and white berry extracts exhibited noticeable ameliorations in TNF- $\alpha$, IL-1 $\beta$, TGF- $\beta$ levels and PON1 activity as well as low apoptosis rates and decreased the alteration of the pro-apoptosis and inflammatory related genes.
\end{abstract}

Conclusion: Red and white berry extracts exhibited attenuation in antioxidant status, suppressed inflammatory cytokines, apoptosis and the alterations in the apoptosis and inflammatory related genes induced by STZ in male rats.

Keywords: Red berry, White berry, STZ, Diabetes, TNF- $\alpha$, IL-1 $\beta$, Apoptotic gene, NF- $\kappa$ B1 and AIF-1

(C) 2016 The Authors. Published by Innovare Academic Sciences Pvt Ltd. This is an open access article under the CC BY license (http://creativecommons.org/licenses/by/4. 0/) DOI: http://dx.doi.org/10.22159/ijpps.2016v8i11.14480

\section{INTRODUCTION}

In the last years, several studies have demonstrated that chronic and low-grade inflammation is closely involved in the type 2 diabetes (T2D) development [1]. The mechanisms are associated with synthesis and release of proinflammatory cytokines, mainly by the adipose tissue [2]. Cytokines are a group of pharmacologically active polypeptides included in several classes: IL, TNF, interferons, colony stimulating factors (CSF), TGF and chemokines which participate as humoral mediators and coordinate a network regulating inflammatory immune responses. Furthermore, they exert important pleiotropic actions as cardinal effectors of damage [2]. Several studies showed that the activation of the innate immune system is also involved in T2D. The immune system modulates the effects of many factors including genes, cytokine levels and metabolic events associated with insulin resistance [3]. TGF- $\beta 1$ is an anti-inflammatory immune mediator which inhibits or reverses the activation of macrophages by interfering with signaling via toll-like receptor-dependent pathways. Herder et al. [4] reported that high levels of TGF- $\beta 1$ were associated with T2D and elevated IL-1Ra concentration, whose increase precedes the development of T2D. Therefore, pro-and anti-inflammatory mediators are present in T2D and TGF- $\beta 1$ may act in both sides.

It has been reported that PON1 plays a crucial role in the antioxidant activity of high-density lipoproteins (HDL) by protecting low-density lipoproteins (LDL), against lipid peroxidation and thus attenuates the development of atherosclerosis [5]. In fact, PON1-deficiency increased oxidative stress not only in serum but also in macrophages, a phenomenon that can contribute to accelerated atherosclerosis [6]. PON1 also exerts a protective effect against oxidative damage of cells and modulates the susceptibility of HDL and LDL to atherogenic changes such as homo cysteinylation [7]. In addition, it modulates the anti-inflammatory role of HDL [8]. Moreover, low PON1 activity has been found in numerous pathological conditions associated with atherosclerosis, including type 1 and 2 diabetes, hypercholesterolemia and metabolic syndrome, as well as in elderly populations [9]. All these conditions display a pro-inflammatory baseline state that could be due to low PON1, as its activity is inversely related to cardiovascular risk [10].

Hyperglycemia can induce apoptosis of renal cells result in diabetic nephropathy [11]. Reactive oxygen species (ROS) induced by drugs lead to considerable cellular damage to the point of no return in apoptosis when insufficient cytoprotective and ROS scavenging molecules are available [11]. However, discussing the relation between apoptosis in liver tissues of STZ treated rats and gene expression alteration was not discussed yet.

Apoptosis or programmed cell death is a genetically controlled, physiological process essential for normal tissue development and homeostasis. It has been proposed that limiting tissue damage associated with chronic inflammation is related to the suppression of apoptosis of ocular surface cells [12]. The best-known mediators of apoptosis are caspases, which are cysteine-dependent, aspartatespecific proteases involved in pro-inflammatory cytokine activation and are the effectors of apoptotic pathways [13].

Sequential activation of caspases plays a central role in the execution-phase of cellapoptosis. Caspases exist as inactive proenzymes that undergo proteolytic processing at conserved aspartic residues to produce two subunits, large and small, that dimerize to form the active enzyme. The proteolytic cleavage of this protein is induced by a variety of apoptotic stimuli [14]. Caspase 1 has been shown to induce cell necrosis or pyroptosis and may function in various developmental stages [15]. Recent studies implicated caspase 1 in promoting CD4 T-cell death and inflammation by human immunodeficiency virus (HIV), two signature events that fuel HIV disease progression to acquired immune deficiency syndrome (AIDS) [16, 17]. Caspase 2 proteolytically cleaves other proteins. It belongs to a family of cysteine proteases called caspases that cleave proteins only at an amino acid following an aspartic acid residue. Caspase 2 has a similar amino acid sequence to initiator caspases, 
including caspase 1 , caspase 4 , caspase 5 and caspase 9 . It is produced as a zymogen which contains a long pro-domain that is similar to that of caspase 9 and contains a protein interaction domain known as a caspase activation and recruitment domain (CARD) . Pro-caspase- 2 contains two subunits, p19 and p12 [18].

In addition to the caspase family gene, eotaxin gene is one of the proapoptotic genes. It is encoding a protein belong to cytokines. Eotaxin causes the rapid accumulation of eosinophils in guinea pig lung [19] and has been identified as an important eosinophil chemoattractant in both mouse and man $[20,21]$. The recent study reported that eotaxin is a ligand for C-C chemokine receptor type 5 (CCR5) [22] may explain the macrophage accumulation that occurred at $24 \mathrm{~h}$. However, infiltrating leukocytes may often be sources of proinflammatory chemokines and it is more likely that the delayed recruitment of macrophages into the tissue reflects secondary processes dependent upon the induction of other chemokines rather than being dependent directly upon the action of eotaxin or eotaxin2. Nuclear factor kappa-light-chain-enhancer of activated B cells $(\mathrm{NF}-\mathrm{KB})$ is a protein complex that controls transcription of DNA, cytokine production and cell survival. NF- $\mathrm{\kappa B}$ is found in almost all animal cell types and is involved in cellular responses to stimuli such as stress, cytokines, free radicals, ultraviolet irradiation, oxidized LDL, and bacterial or viral antigens [23-27]. NF- $\mathrm{KB}$ plays a key role in regulating the immune response to infection ( $\kappa$ light chain is critical components of immune-globulins). Incorrect regulation of $\mathrm{NF}-\mathrm{KB}$ has been linked to cancer, inflammatory and autoimmune diseases, septic shock, viral infection and improper immune development. NF- $\kappa \mathrm{B}$ has also been implicated in processes of synaptic plasticity and memory [28-32].

Allograft inflammatory factor-1 (AIF1) is a protein that exists in the cytoplasm and it is highly evolutionarily conserved. It is also possibly identical to three other proteins, IBA-1, MRF-1 (microglia response factor) and daintain. However, complete functional profiles of all three proteins and how they overlap is unknown [33]. IBA1 is a $17-\mathrm{kDa}$ EF-hand protein that is specifically expressed in macrophages/ microglia and is up-regulated during the activation of these cells. IBA1 expression is up-regulated in microglia following nerve injury, [34] central nervous system ischemia and several other brain diseases.

On the other hand, berries red and white (Moraceae) cantain large amount of polyphenols which are secondary metabolites of plants and are generally involved in defense against ultraviolet radiation or aggression by pathogens [35]. In food, polyphenols may contribute to the bitterness, astringency, color, flavor, odor and oxidative stability. Towards the end of $20^{\text {th }}$ century, epidemiological studies and associated meta-analyses strongly suggested that long-term consumption of diets rich in plant polyphenols offered protection against the development of cancers, cardiovascular diseases, and diabetes, osteoporosis and neurodegenerative diseases [36, 37]. Polyphenols and other food phenolics are the subjects of increasing scientific interest because of their possible beneficial effects on human health.

Although several works had been focused on the therapy of diabetes, the present study aimed to use red and white berry extracts to evaluate their ameliorative effect against the oxidative stress effect of diabetes including alteration in the expression of apoptosis and inflammation-related genes occurred in diabetes mellitus (DM)induced rats.

\section{MATERIALS AND METHODS}

\section{Chemicals}

STZ was purchased from Sigma-Aldrich, India. TRIzol reagent was bought from Invitrogen (Germany). The reverse transcription and PCR kits were obtained from Fermentas (USA). SYBR Green Mix was purchased from Stratagene (USA). All kits were the products of Biosystems (Alcobendas, Madrid, Spain), Sigma Chemical Company (St. Louis, MO, USA), Bio diagnostic Company (Cairo, Egypt).

\section{Red and white berry fruit ethanolic extracts preparation}

Red and white berry fruits were obtained from the local market, Egypt during July 2015. The plant was kindly authenticated by Mrs
Treas Labib, Herbarium section, El-Orman Botanical Garden, Giza, Egypt with voucher specimen of 0111236,01112235 respectively for red and white berries. Berries were grinded and extracted three times with ethanol 70\%. The extracts were filtered through filter paper and each filtrate was concentrated under vacuum using Rotary evaporator (Heidolph-Germany) till dryness [38, 39]. The crude extracts were obtained and stored at $4{ }^{\circ} \mathrm{C}$ for further investigations.

\section{Biological experiment}

\section{Animals and rout of administration}

The male Wistar albino rats $(150 \pm 20 \mathrm{~g})$ were provided by the Animal House of the National Research Centre (NRC) and housed in group of 10 rats per cage, maintained in controlled environment condition at $26-29{ }^{\circ} \mathrm{C}$ and were provided with a fixed light/dark cycle for one week $(\mathrm{w})$ as an adaptation period to acclimatize under normal combination with free access to water and food. The study was approved (approval no: 1456) by the Ethical Committee of the NRC, Egypt, provided that the animals will not suffer at any stage of the experiment.

The basal diet, salt mixture, and vitamin mixture were formulated according to AOAC [40] as shown in tables (1,2 and 3).

Table 1: Formulation of basal diet

\begin{tabular}{ll}
\hline Ingredients & Weight (\%) \\
\hline Casein & 15 \\
Corn oil & 10 \\
Cellulose & 5 \\
Vitamin mixture & 1 \\
Salt mixture (free iron) & 4 \\
Starch & 15 \\
\hline
\end{tabular}

Table 2: Description of salt mixture

\begin{tabular}{ll}
\hline Ingredients & Weight \\
\hline $\mathrm{CaCO}_{3}$ & 600 \\
$\mathrm{~K}_{2} \mathrm{HPO}_{4}$ & 645 \\
$\mathrm{CaHPO}_{4} .2 \mathrm{H}_{2} \mathrm{O}$ & 118 \\
$\mathrm{NaCl}_{\mathrm{Fe}\left(\mathrm{C}_{6} \mathrm{H}_{5} \mathrm{O}_{7}\right) 6 \mathrm{H}_{2} \mathrm{O}}$ & 334 \\
$\mathrm{CuSO}_{4} 5 \mathrm{H}_{2} \mathrm{O}$ & 55 \\
$\mathrm{MgSO}_{4} .7 \mathrm{H}_{2} \mathrm{O}$ & 0.6 \\
$\mathrm{Kl}$ & 204 \\
$\mathrm{ZnCl}_{2}$ & 1.6 \\
$\mathrm{MnSO}_{4}$ & 0.5 \\
\hline
\end{tabular}

Table 3: Formulation of vitamin mixture

\begin{tabular}{ll}
\hline Vitamins & Amount \\
\hline Vitamin A & $2000 \mathrm{IU}$ \\
Vitamin D & $200 \mathrm{IU}$ \\
Vitamin E & $10 \mathrm{IU}$ \\
Vitamin B & $2.0 \mathrm{mg}$ \\
Vitamin K & $10 \mathrm{mg}$ \\
Vitamin E & $0.5 \mathrm{mg}$ \\
Biotin & $0.04 \mathrm{mg}$ \\
Pyridoxine & $0.4 \mathrm{mg}$ \\
Niacin & $4 \mathrm{mg}$ \\
Inositol & $10 \mathrm{mg}$ \\
Folic acid & $0.2 \mathrm{mg}$ \\
Choline chloride & $200 \mathrm{mg}$ \\
Pantothenic acid & $4 \mathrm{mg}$ \\
Riboflavin & $1 \mathrm{mg}$ \\
Para aminobenzoic acid & $10 \mathrm{mg}$ \\
\hline
\end{tabular}

\section{Experimental design and diabetes induction}

Seventy rats were divided randomly into six groups of 10 rats each. 
Group 1: Normal healthy control untreated rats.

Group 2: Red berry extract treated normal control rats.

Group 3: White berry extract treated normal control rats.

Group 4: STZ injected rats where T2D was induced by intraperitoneally injection of a single dose of STZ $(45 \mathrm{mg} / \mathrm{kg}$ body weight [41] dissolved in $0.01 \mathrm{M}$ citrate buffer immediately before use. After injection, animals had free access to food, water and were given 5\% glucose solution to drink overnight to encounter hypoglycemic shock [42]. Animals were checked daily for the presence of glycosuria, hyperglycemia. Animals were considered to be diabetic if glucosuria was present for 3 consecutive days (d) [43]. Three days after STZ injection, fasting blood samples were obtained, and blood sugar was determined $(\geq 300 \mathrm{mg} / \mathrm{dl})$.

Group 5: Diabetic rats treated with ethanolic extract of red berry (300 mg/kg b. wt.) for $30 \mathrm{~d}$ [44].

Group 6: Diabetic rats treated with ethanolic extract of white berry (300 mg/kg b. wt.) for $30 \mathrm{~d}$ [44].

Group 7: Diabetic rats treated with standard drug glibenclamide (10 $\mathrm{mg} / \mathrm{kg} \mathrm{b}$. wt.) daily for $30 \mathrm{~d}$ [45]. The glycemia was checked during all the course of the experiments.

\section{Blood sample preparation}

Overnight fasted animals were sacrificed under slight diethyl ether anesthesia, and blood was collected by puncture of the sublingual vein in clean and dry test tube. Blood was left $10 \mathrm{~min}$ to clot and centrifuged (Sigma, 4-16KS) at $3000 \mathrm{rpm}$ to obtain serum. The separated serum was used for biochemical analysis of inflammatory biomarkers; TNF- $\alpha$ and IL-1 $\beta$ TGF- $\beta$ and PON1.

\section{Biochemical analyses}

TNF- $\alpha$, IL-1 $\beta$, TGF- $\beta$ and PON1 were performed by ELISA; a sandwich enzyme immunoassay (Sigma Chemical Company, USA).

\section{Apoptosis assay}

The tissue of liver (50 mg per sample) was made into single-cell suspensions according to a method of Villalba et al. [46]. Cells apoptosis was determined by flow cytometry (FCM) assay using Annexin V/PI apoptosis detection kit. The single-cell suspension $\left(1 \times 10^{6}\right.$ cells $\left./ \mathrm{ml}\right)$ was suspended in $200 \mu \mathrm{l}$ ice-cold binding buffer and then $10 \mu \mathrm{l}$ horseradish peroxidase fluorescein isothiocyanate (FITC) labeled Annexin V and $5 \mu \mathrm{l}$ propidium iodide (PI) were added. The cell suspension was incubated in darkness at room temperature for $15 \mathrm{~min}$. Apoptosis rate was determined by flow cytometer. In this study, both FITC and PI negative cells were considered as normal cells. FITC-single positive and PI negative cells were defined as early apoptotic cells, while both FITC and PI positive cells were considered as late apoptotic or necrosis cells.

\section{Gene expression analysis \\ Extraction of total RNA and cDNA synthesis}

Liver tissues of male rats were used to extract the total RNA using TRIzol@ Reagent (Invitrogen, Germany) Kit. The isolation method was carried out according to the manufacturer's instructions of the above Kit. Approximately $50 \mathrm{mg}$ of the liver tissues were mixed with some drops of liquid nitrogen and homogenized in $1 \mathrm{ml}$ of TRIzol@ Reagent in autoclaved mortar. Afterward, total RNA was dissolved and preserved in diethyl pyrocarbonate (DEPC)-treated water up to use.

To assess the RNA yield and purity of the total RNA, RNAse-free DNAse I (Invitrogen, Germany) was used to digest DNA contamination. A small drop of isolated RNA was examined photo spectrometrically at $260 \mathrm{~nm}$. The purity of total RNA was determined between 1.8 and 2.1 to be good purified when it examined by photo spectrometer at the $260 / 280$ nm ratio. To avoid RNA damage, aliquots of RNA were prepared after isolation for either reverse transcription reaction or otherwise for storing at $-80^{\circ} \mathrm{C}$ up to use.

To synthesize the complementary DNA (cDNA), isolated RNA from liver tissues was reverse transcribed into cDNA. The reaction volume was carried out in $20 \mu$ l. The reaction volume was prepared according to the instructions of the RevertAidTM First Strand cDNA Synthesis Kit (MBI Fermentas, Germany). The reverse transcription (RT) reaction was performed for $10 \mathrm{~min}$ at $25^{\circ} \mathrm{C}$. Afterward, the tubes of the reaction were put in thermocycler machine for $60 \mathrm{~min}$ at $42{ }^{\circ} \mathrm{C}$, and then the reaction was terminated for $5 \mathrm{~min}$ at $99^{\circ} \mathrm{C}$. The PCR products containing the cDNA were kept at- $20^{\circ} \mathrm{C}$ up to use for DNA amplification.

\section{Quantitative real time-PCR (qRT-PCR)}

A Step One Real-Time PCR System (Applied Biosystem, USA) was used to assess the copy of the cDNA of male rats to detect the expression values of the tested genes. To perform the PCR reaction, a volume of $25 \mu \mathrm{l}$ of reaction mixtures was prepared containing $12.5 \mu \mathrm{l}$ of SYBR® green (TaKaRa, Biotech. Co. Ltd.), $0.5 \mu \mathrm{l}$ of $0.2 \mu \mathrm{M}$ forward and reverse primers, $6.5 \mu \mathrm{l}$ DNA-RNA free water and $2.5 \mu \mathrm{l}$ of the synthesized cDNA. The cDNA was propagated using reaction program consisted of 3 steps. In the first step, the PCR tubes were incubated at $95^{\circ} \mathrm{C}$ for $3 \mathrm{~min}$. In the second step, the reaction program consisted of 50 cycles. Each cycle of them consisted of 3 sub-steps: (a) $15 \mathrm{sec}$ at $95^{\circ} \mathrm{C}$; (b) $30 \mathrm{sec}$ at $60^{\circ} \mathrm{C}$; and (c) $30 \mathrm{sec}$ at $72^{\circ} \mathrm{C}$. In the third step, the reaction program consisted of 71 cycles. The first cycle of them started at $60^{\circ} \mathrm{C}$ for $10 \mathrm{sec}$ and then the followed cycles increased about $0.5{ }^{\circ} \mathrm{C}$ every $10 \mathrm{sec}$ up to $95{ }^{\circ} \mathrm{C}$. A melting curve of the reaction was performed for each qRT-PCR termination at $95^{\circ} \mathrm{C}$ to assess the quality of the primers. To verify that, the reaction of the qRT-PCR does not have any contamination, PCR tubes containing non-template control were used. The sequences of the specific primer of the genes used are listed in the table (4). Primers for the gene sequences in this study were designed by using Primer 3 software (http://bioinfo.ut.ee/primer3/). The relative quantification of the target genes to the reference ( $\beta$-Actin) was determined by using the $2-\Delta \Delta$ CT method.

Table 4: Primer sequences used for qPCR

\begin{tabular}{lll}
\hline Gene & Primer sequence (5'-3') & References \\
\hline Eotaxin & F: CACCATGCAGCTCTCCACAG & Y08358 \\
& R: CAGTAGTGTGTTGGGGATCTTCTT & U14647 \\
Caspase-1 & F: TCTAAGGGAGGACATCCTTTCTC & \\
& R: TGGGCTATTTCTAAAGGGCAAAAC & U77933 \\
Caspase-2 & F: CCCTTCTCGGTGTGTGAGTC & L26267 \\
& R: GCTGGTAGTGTGCCTGGTAAA & \\
NF-kB1 & F: CAAGCAGGAAGATGTGGTGGA & U17919 \\
AIF-1 & R: ATCATGTCCTTCTTTGGCAGCTA & Deng et al. [47] \\
& F: GCGAATGCTGGAGAAACTTGG & \\
-actin & R: TGAGAAAGTCAGAGTAACTGAACG & Ahmed et al. [48] \\
GAPDH & F: GGAGATTACTGCCCTGGCTCCTA & \\
& R: GACTCATCGTACTCCTGCTGCTG & \\
\hline
\end{tabular}

F: a forward primer; R: a reverse primer; NF-кB1: Nuclear factor kappa beta p105; AIF-1: Allograft inflammatory factor-1. 


\section{Statistical analyses}

The data were statistically analysed using analysis of variance (ANOVA) and Co-state computer program. Data from the test groups were compared with their respective controls and differences at $p \leq 0.05$ were considered to be significant. In addition data were analyzed by ANOVA using the Statistical Package for the Social Sciences (SPSS) program, version 11 followed by least significant difference (LSD) to compare significance between groups. The difference was considered significant when when unshared letters at $\mathrm{P} \leq 0.05$.

\section{RESULTS AND DISCUSSION}

\section{Effect of red and white berry extracts on inflammatory} biomarkers

Table (5) showed the effect of red and white berry extracts on inflammatory biomarkers in control and diabetic treated groups. Marked increase in TNF- $\alpha$, TGF- $\beta$, and IL- $1 \beta$ levels was noticed in diabetic rats with percentages 300.12, 89.59 and $94.94 \%$, respectively. While, a significant reduction in PON1 activity was detected. Red and white berry extracts, as well as glibenclamide, improved the level of TNF- $\alpha$ with percentages reached to 248.82, 148.67 and $110.12 \%$, respectively. In addition, red, white berry extracts and glibenclamide reduced the levels of TGF- $\beta$ and IL1-B with improvement percentages $57.75,24.00$ and $47.20 \%$, respectively for TGF level and $70.88,60.76$ and $49.37 \%$, respectively for the IL1-B level. However, for PON1 activity the percentage of improvement was 23.81, 13.93 and $15.10 \%$, for red, white and glibenclamide, respectively. Hence, the high levels of TNF- $\alpha$, IL-1 $\beta$, TGF- $\beta$ and low activity of PON1 in diabetic rats may be explained on the basis of the prevalent source of oxidative stress (OS) in liver disorders emerges from stimulated hepatic phagocytes and Kupffer cells (KCs) [49]. Immune cells take part in deep-seated inflammatory liver disorders such as diabetes and their participation in these syndromes can consider their induction as a tissue reply to oxidative injury [49]. Stimulated KCs, by NF-kB leads to B cells activation intermediated technicality, output a convention and extremely, interacting inflammatory biomarkers and cytokines, as TNF- $\alpha$, IL-6, IL$1 \beta$, IL-18, inducible nitric oxide synthase (iNOS), IL-12 and provide them to give free radicals as superoxide and endocytose bacteria [49, 50]. NFkB provides various genes contributed to the response of cells to oxidative injuries, such as growth factors, genes of cytokines and adhesion molecules. Moreover, NADPH proteins may induce, in the hepatocytes, the release of ROS in which it initiate DNA destruction, expression of a gene implicated in the production of pro-inflammatory cytokines, stimulate program cell death and enhance their turnover into cancer cells $[51,52]$. iNOS may trigger toxicity of hepatocyte by elevating NOS output [53]. Many of these cytokines may stimulate proapoptotic mechanisms through a cascade of the caspases [49]. In various hepatic syndromes, apoptosis removes a crucial hepatocytes number, resulting in liver function deterioration [49].

TGF- $\beta$ is a principle controlling of extracellular matrix (ECM) protein synthesis in renal cells. TGF- $\beta 1$ in mesangial cells in vitro, but not in podocytes, is stimulated by hyperglycemia, glycated albumin and advanced glycation end product (AGE) [54]. It was found that active TGF- $\beta 1$ is extremely absent in diabetic nephropathy of human and rats, while podocytes demonstrate high TGF- $\beta 1$ expression level [24$28,54]$. In this case, it is suggested that inherent TGF- $\beta$ liberated by mesangial cells is restricted to the podocytes and that induced TGF- $\beta$ in podocytes cause glomerular basement membrane (GBM) condensation and mesangial matrix aggregation in diabetic glomeruli [55]. However, the operative TGF- $\beta$ form has a very short half-life in plasma, and it is improbable for activate TGF- $\beta$ in podocytes to cross the GBM to elicit mesangial sclerosis. Alternatively, TGF- $\beta$-stimulated connective tissue growth factor (CTGF) and vascular endothelial growth factor (VEGF) released from podocytes appear to cross the GBM versus glomerular filtration flow to do on the mesangial cells [54]. Hence, the stimulation of renal TGF- $\beta$ and TGF- $\beta$-initiated glomerular injury in diabetic syndrome and TGF- $\beta$-stimulated CTGF and VEGF could involve in diabetic nephropathy progress.

With respect to PON1, the low activity of PON1 in the present results is closely associated with cardiovascular disease in DM $[56,57]$. Various elements may participate in these alterations. Primarily, the oxidative injury is enhanced and stimulated hence lipid and protein oxidation that may involve in deterioration of vascular membrane [58]. Secondarily, proteins glycation including enzymes may inhibit their effectiveness in diabetes [59]. From the results of the present study, it could be ascertained that the activity of serum PON1 is markedly decreased in diabetic rats. Peroxidation of LDL has a principle effect in atherogenesis [60]. It was demonstrated that enzymes linked with HDL molecules such as PON1, plateletactivating factor acyltransferase and lecitin-cholesterol acyltransferase (LCAT) can relieve oxidized lipids from LDL. Also, HDL reduces lipid peroxides aggregation in LDL primarily due to paraoxonase activity. In vitro, PON1 preserved LDL from the copperstimulated LDL-combined dienes. The combination between PON1 gene polymorphisms and cardiovascular disease could be subsequently affected by these enzyme-defensive actions in vivo. Suppress PON1 activity reduces the capability to illicit lipid-peroxide synthesis leading to oxidative injury. High level of free radicals output in diabetic subjects may be related to deep-seated hyperglycemia, hyperinsulinemia, high levels of free fatty acids (FFA) and dyslipidemia [60]. Plasma lipids also alter synthesis, role and content of the HDL. High triglyceride-rich lipoproteins may exchange cholesterol esters in HDL by lead cholesterol ester transfer protein (CETP) with further HDL deficiency of cholesterol esters. So, the structure and role of HDL may be changed. Glycation of HDL or PON1 in HDL in diabetes may cause separation of PON1 from HDL molecule with subsequent PON1 inactivation [57]. The inhibition in PON1 enzyme activity is produced rather by glycation than by its low composition [58]. PON1 is joined with HDL in a minimal range in diabetic subjects comparing with normal controls and its activity is then inhibited [58]. The present findings suggested that lipid preservation by PON1 versus oxidation may be diminished in diabetic rats because of enzyme inhibition.

Table 5: Effect of Red and white ethanolic extract on inflammatory biomarkers in normal and STZ-induced diabetic rats

\begin{tabular}{|c|c|c|c|c|c|}
\hline Groups & Parameters & TNF- $\alpha(\rho g / \mathrm{ml})$ & TGF- $\beta(\mathrm{Pg} / \mathrm{ml})$ & IL-1 $\beta(\eta g / m l)$ & PON1 (U/l) \\
\hline Normal control & mean \pm SD & $100.00 \pm 9.00^{\mathrm{e}}$ & $250.23 \pm 24.74 \mathrm{e}$ & $1.58 \pm 0.03^{\mathrm{d}}$ & $10.12 \pm 0.52$ a \\
\hline Red berry extract treated normal control & mean $\pm S D$ & $88.00 \pm 6.50^{\mathrm{a}}$ & $250.20 \pm 10.14$ e & $1.50 \pm 0.05^{\mathrm{d}}$ & $11.19 \pm 1.02 \mathrm{a}$ \\
\hline$\%$ Change to control & & 20 & 0.01 & 5.00 & 10.57 \\
\hline White berry extract treated normal control & mean $\pm S D$ & $90.55 \pm 8.08 \mathrm{e}$ & $244.11 \pm 20.00$ e & $1.60 \pm 0.04^{\mathrm{d}}$ & $11.00 \pm 1.12$ a \\
\hline$\%$ Change to control & & 9.45 & 2.44 & 1.26 & 8.69 \\
\hline Diabetic rats & mean $\pm S D$ & $400.12 \pm 10.12^{\mathrm{a}}$ & $474.42 \pm 18.87$ a & $3.08 \pm 0.1^{\mathrm{a}}$ & $6.05 \pm 0.07$ e \\
\hline$\%$ Change to control & & 300.12 & 89.59 & 94.94 & 40.30 \\
\hline Red berry extract treated diabetic rats & mean $\pm S D$ & $151.30 \pm 2.11^{c}$ & $329.92 \pm 7.62 b$ & $1.96 \pm 0.04 \mathrm{c}$ & $8.46 \pm 0.06^{\mathrm{d}}$ \\
\hline$\%$ Change to control & & 51.30 & 31.84 & 24.05 & 16.40 \\
\hline$\%$ of improvement & & 248.82 & 57.75 & 70.88 & 23.81 \\
\hline White berry extract treated diabetic rats & mean $\pm S D$ & $251.45 \pm 6.80^{f}$ & $400.85 \pm 13.35^{c}$ & $2.12 \pm 0.12^{c}$ & $7.46 \pm 0.06^{b}$ \\
\hline$\%$ Change to control & & 151.45 & 60.19 & 34.177 & 26.28 \\
\hline$\%$ of improvement & & 148.67 & 24.00 & 60.76 & 13.93 \\
\hline Diabetic + glibenclamide drug & mean \pm SD & $290.00 \pm 5.10 \mathrm{~g}$ & $356.30 \pm 5.78^{d}$ & $2.30 \pm 0.16^{\mathrm{k}}$ & $7.66 \pm 0.19$ b \\
\hline$\%$ Change to control & & 190.00 & 42.39 & 45.57 & 24.30 \\
\hline$\%$ of improvement & & 110.12 & 47.20 & 49.37 & 15.10 \\
\hline
\end{tabular}

- Values are expressed as mean \pm SD for 10 rats, Statistical analysis is carried out using Co-state and SPSS computer programs (Version 7), where unshared letter is significant at $\mathrm{P} \leq 0.05$. 


\section{CALCULATION}

$$
\begin{aligned}
& \% \text { Change to control }=\frac{\text { Mean of control }- \text { Mean of treated }}{\text { Mean of control }} \times 100 \\
& \% \text { of improvement }=\frac{\text { Mean of disease }- \text { Mean of treated }}{\text { Mean of control }} \times 100
\end{aligned}
$$

Effect of red and white berry extracts on the apoptosis rate in STZ-treated rats

The effect of berry extracts on the inhibition of the apoptosis rates induced STZ is summarized in fig. (1). The results revealed that STZinduced T2D in male rats increased apoptosis rates to $522 \%$ as compared to normal untreated rats. In contrast, the apoptosis rates were reduced when STZ exposed-rats treated with red or white berry (259.8 and 314.6\%, respectively) compared with those in STZtreated rats (fig. 1). In addition, the effect of the standard drug for diabetes treatment, glibenclamide, on the apoptosis rates was relatively similar to that of red berry where the apoptosis rate was 273.2\% compared with that in STZ-treated rats (fig. 1).

\section{Red and white berry extracts impact on the alteration of gene} expression in STZ-treated rats

The expression values of the pro-apoptosis (eotaxin, caspase- 1 , and caspase-2) and inflammation (NF-kB1 and AIF-1) related genes in liver tissues of male rats were quantified by real-time RT-PCR (fig. 2-6). The results revealed that exposure of male rats with STZ increased the mRNA expression values of eotaxin, caspase- 1 , caspase-2, NF- $\mathrm{kB} 1$ and AIF-1 genes to $254.6,241.5,268.9,518.6$, and $563.2 \%$, respectively compared with control rats (fig. 2-6). On the other hand, expression values of GLT-1 eotaxin, caspase-1, caspase-2, NF- $\mathrm{kB} 1$ and AIF-1 genes decreased to $189.1,154.5,154.0,295.3$ and $323.7 \%$ respectively in STZinduced rats treated with red berry extract compared with STZ-treated rats (fig. 2-6). Moreover, expression values of GLT-1 eotaxin, caspase-1, caspase-2, NF-кB1 and AIF-1 genes decreased to 259.4, 176.6, 187.4, 351.2 and $373.7 \%$, respectively in STZ-induced rats treated with white berry extract compared with STZ-treated rats (fig. 2-6). In addition, the effect of the drug, glibenclamide, on the gene expression alteration was relatively similar to that of red berry when, expression values of GLT-1 eotaxin, caspase-1, caspase-2, NF- $\mathrm{KB} 1$ and AIF-1 genes decreased to $206.3,164.9,164.4,306.9$ and $339.5 \%$, respectively in STZ-induced rats treated with glibenclamide compared with STZ-treated rats.

The present results declared that diabetic rats exhibited high apoptosis rate in hepatic tissues and changes in the apoptosis and inflammatory-related genes in liver tissues. In agreement with the findings of the present study, Saini et al. [61]. Reported that the cytotoxic effect of STZ on $\beta$-cells in murine pancreatic $\beta$-cell line involves the activation of the apoptotic pathway. In addition, STZ has been shown to induce apoptosis in $\beta$-cells and modifies mouse islet loss after STZ treatment, but the mechanisms involved of STZ are not well understood $[62,63]$. On the other hand, Stennicke and Salvesen [64] and Maedler et al. [65] reported that the apoptosis in human cells increased with STZ treatment is due to the alteration in expression of caspase genes, whereas, high expression levels of caspase genes increase the apoptosis rates in human cells.

Furthermore, several studies reported that STZ treatment reduced glutathione concentration [66]. It has been reported that glutathione impact was observed as a prominent protector against OS and diseases related to diabetes [67]. There are several biological benefits of glutathione in which inhibiting the liver damage is one of the important therapeutic roles. Indeed, the mechanism of action of liver disease is depending upon several factors. However, several synthetic or natural antioxidants were found to control and enhance cell survival of hepatocellular carcinoma (HCC) [53]. Therefore, use of natural antioxidants might be played an unusual therapeutics role in liver treatment.

This study revealed that red and white berry extracts administration ameliorate cytokines, TGF- $\beta$ levels and PON1 activity as well as reduced the apoptosis rates and the alterations in the apoptosis and inflammatory-related genes in induced rats by the STZ. Indeed the biological action of berry extracts against apoptosis and inflammation is not well understood. However, several studies reported that berry extract contained phenolic compounds [68]. It has been found that phenolic compounds produced from the berry fermentation in the colon may reach high and adequate levels to enhance the immune system not only to protect the colon cells but also to protect other organs through its association with other biological processes [68].

Moreover, it has been observed that, either fermentation or digestion of berry extracts were able to protect against DNA damage and mutations induced by a drug or environmental OS [68]. In the same trend, treatment with berry extracts resulted from fermentation or digestion processes exhibited a markedly decrease in the DNA damage and promoted the anti-mutagenic and antiinflammatory activities against a relevant biological challenge [69]. In addition, the microbiota-resulted catabolites of fermented or digested extracts were very efficient in inhibition of the signaling pathway of enzyme and protein molecules associated with inflammation processes [70, 71]. Therefore, it could be suggested that the protective effects of red and white berry extracts in modulating inflammation, antioxidant status, apoptosis and the alterations in the apoptosis and inflammatory related genes might be attributed to the its phenolic compounds contents and/or the microbiota-derived catabolites such as urolithins.

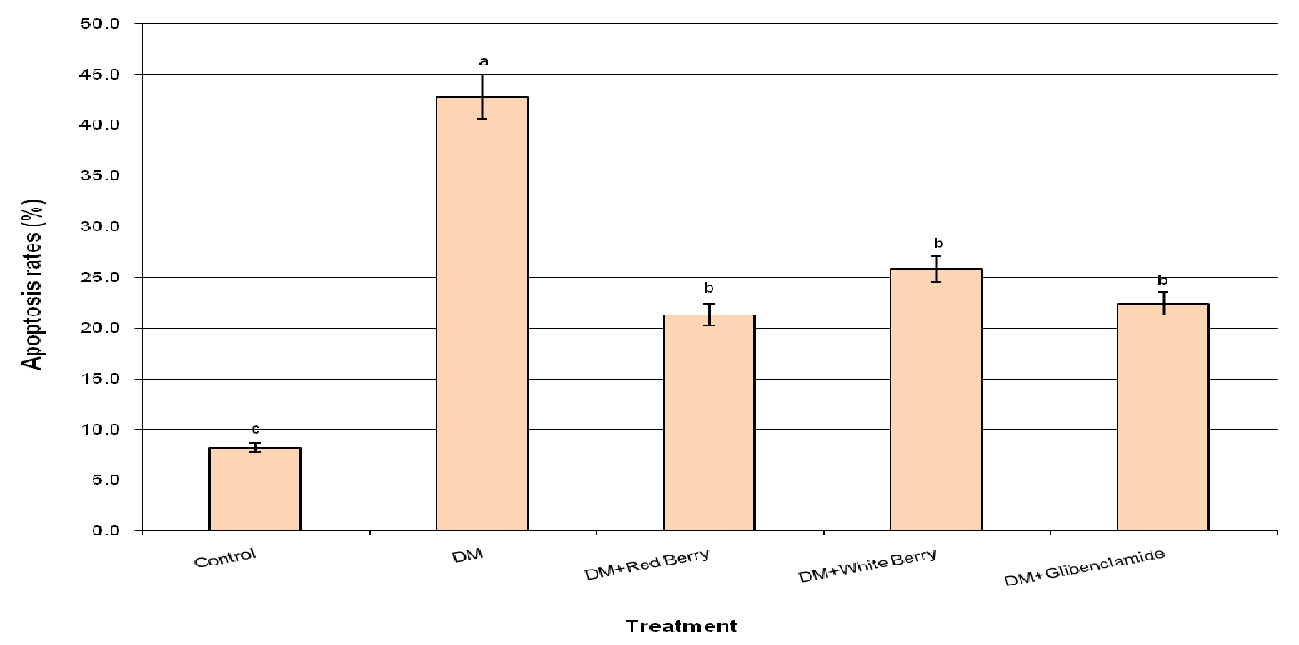

Fig. 1: Levels of apoptosis in liver tissues of STZ-treated rats treated with red berry and white berry extracts. Data are presented as mean $\pm S E M$. a,b,c Mean values with different superscripts are considered significant $(P \leq 0.05)$ 


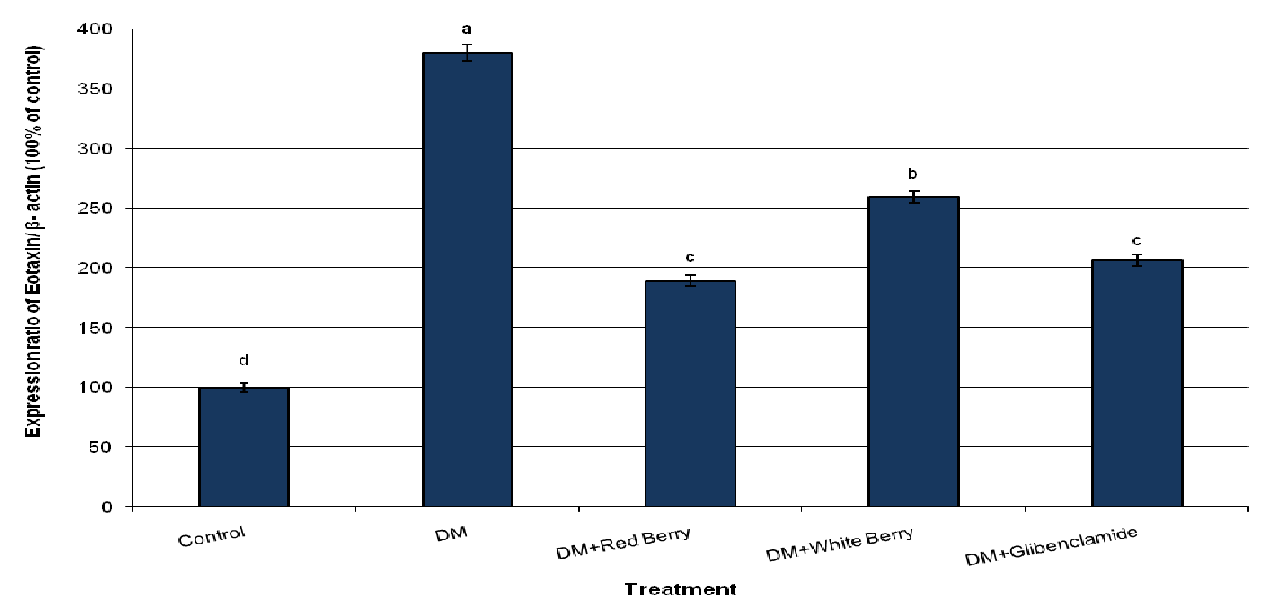

Fig. 2: Expression levels of eotaxin mRNA in liver tissues of STZ-treated rats treated with red berry and white berry extracts. Data are presented as mean $\pm S E M$. $a, b, b, d$ Mean values with different superscripts are considered significant $(P \leq 0.05)$

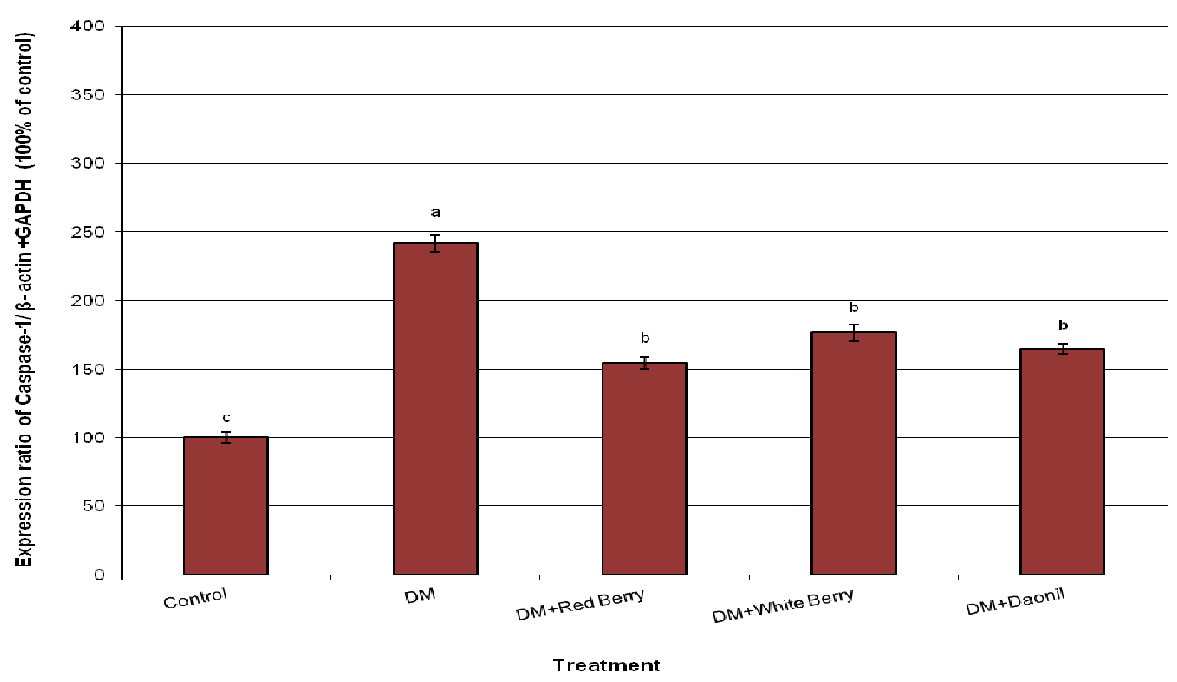

Fig. 3: Expression levels of caspase-1mRNA in liver tissues of STZ-treated rats treated with red berry and white berry extracts. Data are presented as mean \pm SEM. a,b,c Mean values with different superscripts are considered significant $(P \leq 0.05)$

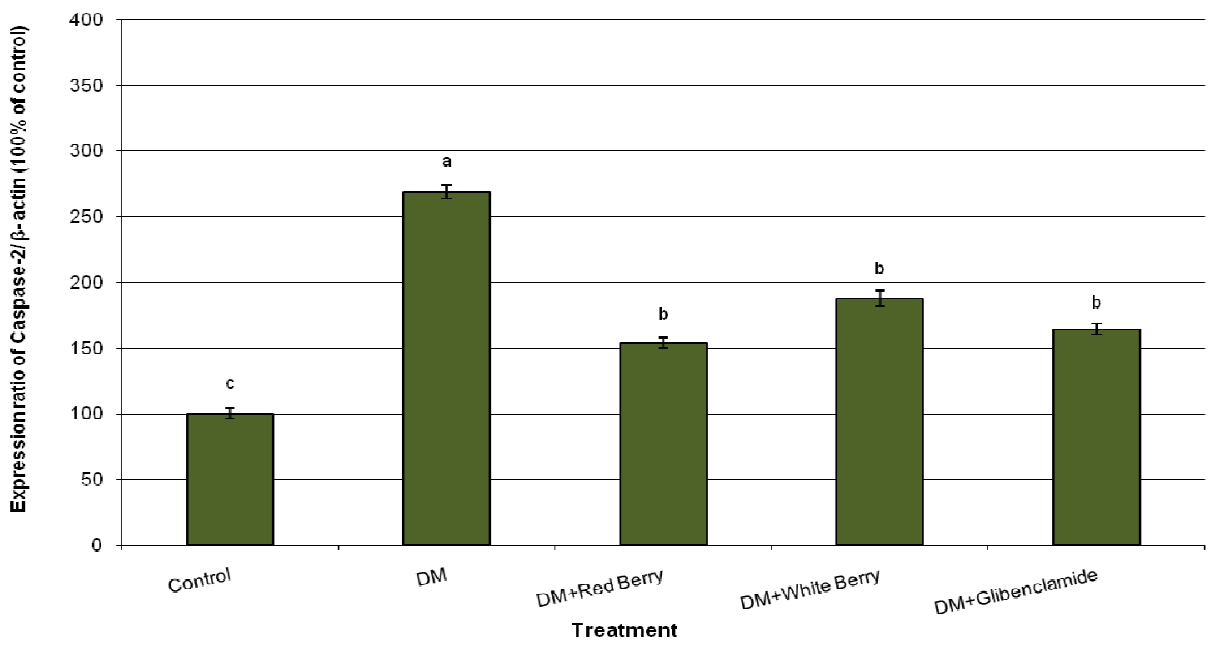

Fig. 4: Expression levels of caspase-2 mRNA in liver tissues of STZ-treated rats treated with red berry and white berry extracts. Data are presented as mean $\pm S E M$. ${ }^{a, b, c}$ Mean values with different superscripts are considered significant $(P \leq 0.05)$ 


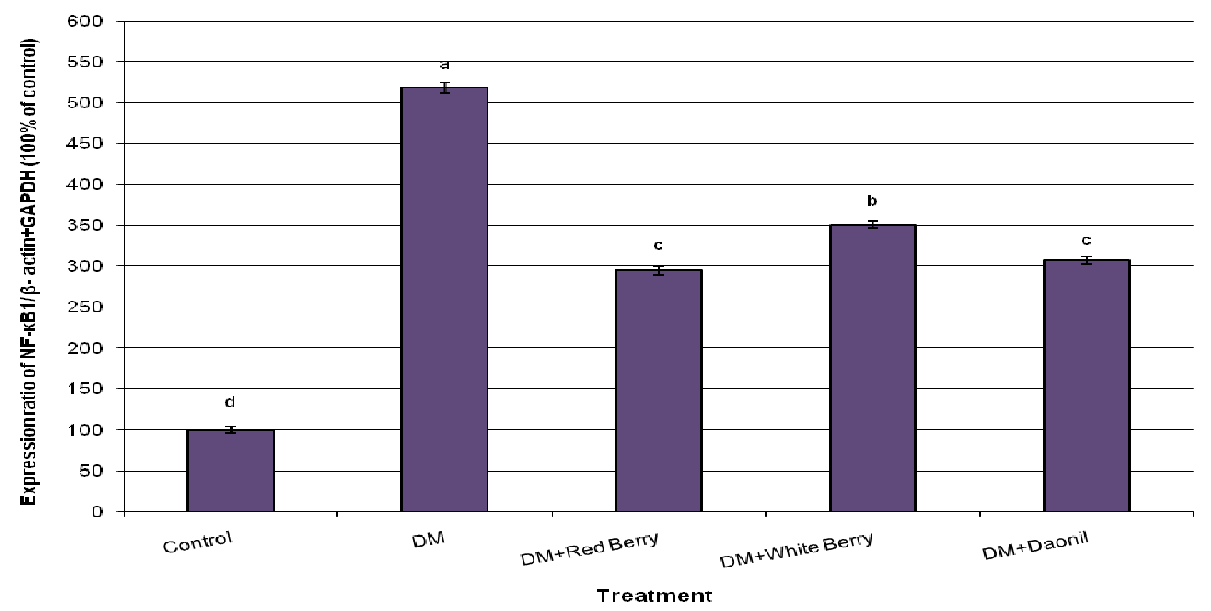

Fig. 5: Expression levels of NF-KB1mRNA in liver tissues of STZ-treated rats treated with red berry and white berry extracts. Data are presented as mean \pm SEM. a,b,c Mean values with different superscripts are considered significant $(\mathrm{P} \leq \mathbf{0 . 0 5})$

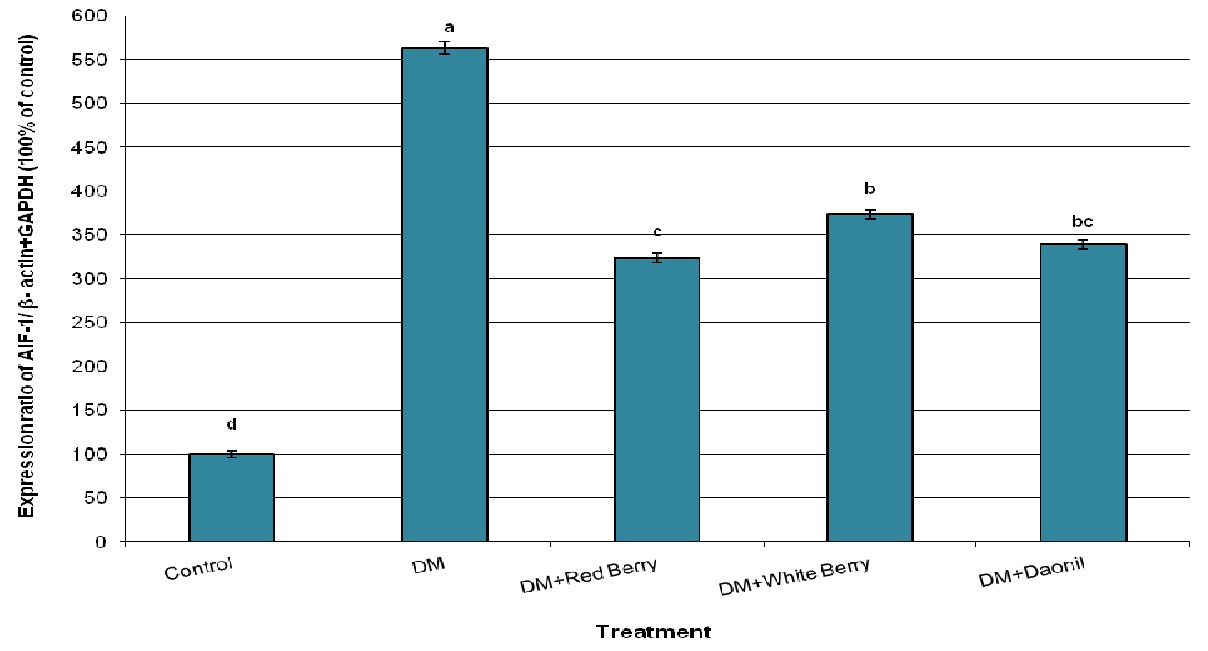

Fig. 6: Expression levels of AIF-1 mRNA in liver tissues of STZ-treated rats treated with red berry and white berry extracts. Data are presented as mean \pm SEM. a,b,c Mean values with different superscripts are considered significant $(P \leq 0.05)$

\section{CONCLUSION}

Red and white berry extracts exhibited attenuation in antioxidant status, suppressed inflammatory cytokines, apoptosis and the alterations in the apoptosis and inflammatory related genes induced by STZ in male rats. The modulating impact of red and white berry extracts might be due to their high phenolic contents.

\section{CONFLICT OF INTERESTS}

Conflict of interest declared none

\section{REFERENCES}

1. Lindarto D, Syafril S, Zein U, Saragih A. The effect of dhawalsan-1 (Curanga fel-terrae [Lour.]) extract versus metformin on the metabolic and inflammatory characteristics of patients with newly diagnosed type 2 diabetes mellitus. Asian J Pharm Clin Res 2016;9:225-8.

2. Navarro-González JF, Mora-Fernández C. The role of inflammatory cytokines in diabetic nephropathy. J Am Soc Nephrol 2008;19:433-42.

3. Ingle PV, Patel DM. C-reactive protein in various disease condition-an overview. Asian J Pharm Clin Res 2011;4:9-13.

4. Herder C, Brunner EJ, Rathmann W. Elevated levels of the antiinflammatory interleukin-1 receptor antagonist precede the onset of type 2 diabetes: the Whitehall II study. Diabetes Care 2009;32:421-3.
5. Durrington PN, Mackness B, Mackness MI. Paraoxonase and atherosclerosis. Arterioscler Thromb Vasc Biol 2001;21:473-80.

6. Rozenberg $\mathrm{O}$, Rosenblat M, Coleman R, Shih DM, Aviram M. Paraoxonase (PON1) deficiency is associated with increased macrophage oxidative stress: Studies in PON1-knockout mice. Free Radical Biol Med 2003;34:774-84.

7. Ferretti G, Bacchetti T. Effect of dietary lipids on paraoxonase-1 activity and gene expression. Nutr Metab Cardiovasc Dis 2012;22:88-94

8. Loued $\mathrm{S}$, Isabelle $\mathrm{M}$, Berrougui $\mathrm{H}$, Khalil $\mathrm{A}$. The antiinflammatory effect of paraoxonase 1 against oxidized lipids depends on its association with high-density lipoproteins. Life Sci 2012;90:82-8.

9. Deakin SP, James RW. Genetic and environmental factors modulating serum concentrations and activities of the antioxidant enzyme paraoxonase-1. Clin Sci (Lond) 2004;107:435-47.

10. Loued S, Berrougui H, Componova P, Ikhlef S, Helal O, Khalil A. Extra-virgin olive oil consumption reduces the age-related decrease in HDL and paraoxonase 1 anti-inflammatory activities. Br J Nutr 2013;110:1272-84.

11. Krijnen PAJ, Simsek S, Niessen HWM. Apoptosis in diabetes. Apoptosis 2009;14:1387-8.

12. Gao J, Gelber-Schwalb TA, Addeo JV, Stern ME. Apoptosis in the lacrimal gland and conjunctiva of dry eye dogs. Adv Exp Med Biol 1998;438:453-60. 
13. Creagh EM, Conroy H, Martin SJ. Caspase-activation pathways in apoptosis and immunity. Immunol Rev 2003;193:10-21.

14. Zhivotovsky B, Orrenius S. Caspase-2 function in response to DNA damage. Biochem Biophys Res Commun 2005;331:859-67.

15. Mariathasan S, Newton K, Monack DM, Vucic D, French DM, Lee WP, et al. Differential activation of the inflammasome by caspase-1 adaptors ASC and Ipaf. Nature 2004;430:213-8.

16. Doitsh G, Galloway NL, Geng X, Yang Z, Monroe KM, Zepeda O, et al. Cell death by pyroptosis drives CD4 T-cell depletion in HIV-1 infection. Nature 2014;505:509-14.

17. Monroe KM, Yang Z, Johnson JR, Geng X, Doitsh G, Krogan NJ, et al. IFI16 DNA sensor is required for death of lymphoid CD4 T cells abortively infected with HIV. Science 2014;343:428-32.

18. Krumschnabel G, Manzl C, Villunger A. Caspase-2:killer, savior and safeguard-emerging versatile roles for an ill-defined caspase. Oncogene 2009;28:3093-6.

19. Humbles AA, Conroy DM, Marleau S, Rankin SM, Palframan RT, Proudfoot AEI, et al. Kinetics of eotaxin generation and its relationship to eosinophil accumulation in allergic airways disease: analysis in a guinea pig model in vivo. J Exp Med 1997; 186:601-12.

20. Rothenberg ME, Maclean JA, Pearlman E, Luster AD, Leder P. Targeted disruption of the chemokine eotaxin partially reduces antigen-induced tissue eosinophilia. J Exp Med 1997;185:785-90.

21. Ponath PD, Qin S, Ringler DJ, Clark-Lewis I, Wang J, Kassam N, et al. Cloning of the human eosinophil chemoattractant, eotaxin: expression, receptor binding and functional properties suggest a mechanism for selective recruitment of eosinophils. J Clin Invest 1996;97:604-12.

22. Ogilvie P, Bardi G, Clark-Lewis I, Baggiolini M, Uguccioni M. Eotaxin is a natural antagonist for CCR2 and an agonist for CCR5. Blood 2001;97:1920-4.

23. Gilmore TD. Introduction to NF-kappa b: players, pathways, perspectives. Oncogene 2006;25:6680-4.

24. Brasier AR. The NF-kappa B regulatory network. Cardiovasc Toxicol 2006;6:111-30.

25. Perkins ND. Integrating cell-signalling pathways with NF-kappa B and IKK function. Nat Rev Mol Cell Biol 2007;8:49-62.

26. Gilmore TD. The Rel/NF-kappa B signal transduction pathway: an introduction. Oncogene 1999;18:6842-4.

27. Tian B, Brasier AR. Identification of a nuclear factor kappa Bdependent gene network. Recent Prog Horm Res 2003;58:95-130.

28. Albensi BC, Mattson MP. Evidence for the involvement of TNF and NF-kappa B in hippocampal synaptic plasticity. Synapse 2000;35:151-9.

29. Meffert MK, Chang JM, Wiltgen BJ, Fanselow MS, Baltimore D. NF-kappa B functions in synaptic signaling and behavior. Nat Neurosci 2003;1072-8.

30. Levenson JM, Choi S, Lee SY, Cao YA, Ahn HJ, Worley KC, et al. A bioinformatics analysis of memory consolidation reveals the involvement of the transcription factor c-rel. J Neurosci 2004;24:3933-43.

31. Freudenthal R, Locatelli F, Hermitte G, Maldonado $H$, Lafourcade C, Delorenzi A, et al. Kappa-B like DNA-binding activity is enhanced after spaced training that induces longterm memory in the crab chasm agnathous. Neurosci Lett 1998;242:143-6.

32. Merlo E, Freudenthal R, Romano A. The Ikappa B kinase inhibitor sulfasalazine impairs long-term memory in the crab chasm agnathous. Neuroscience 2002;112:161-72.

33. Deininger MH, Meyermann R, Schluesener HJ. The allograft inflammatory factor-1 family of proteins. FEBS Lett 2002;514:115-21.

34. Imai $Y$, Ohsawa K, Nakajima K, Fukuuchi $Y$, Kohsaka S. Microglia-specific localization of a novel calcium binding protein, Iba1. Brain Res Mol Brain Res 1998;57:1-9.

35. Pandey KB, Rizvi SI. Plant polyphenols as dietary antioxidants in human health and disease. Oxid Med Cell Longevity 2009;2:270-8.

36. Graf BA, Milbury PE, Blumberg JB. Flavonols, flavonones, flavanones and human health: epidemiological evidence. J Med Food 2005;8:281-90.

37. Arts ICW, Hollman PCH. Polyphenols and disease risk in epidemiologic studies. Am J Clin Nutr 2005;81:317-25.
38. Kanthal LK, Dey A, Satyavathi K, Bhojaraju P. GC-MS analysis of bio-active compounds in methanolic extract of Lactuca runcinata DC. Pharmacogn Res 2014;6:58-61.

39. Ravisankar N, Sivaraj C, Seeni S, Joseph J, Raaman N. GC-MS analysis and anticancer activity of methanol extract of leaves of Hypericum hookerianum wight and ARN. Int J Pharm Pharm Sci 2014;6:515-9.

40. AOAC (Association of Analytical Communities). Official methods of analysis of the Association of Official Analytical Chemistry. 17th ed. AOAC, Gathersubrg, MD, USA; 2005. p. 18.

41. Milani E, Nikfar S, Khorasani R, Zamani MJ, Abdollahi M. Reduction of diabetes-induced oxidative stress by phosphodiesterase inhibitors in rats. Comp Biochem Physiol Part C: Toxicol Pharmacol 2005;140C:251-5.

42. Rajesh RK, Aparna HS, Manjunatha HB. Comparative analysis of silk gland proteins of both heats shocked and normal silkworm larvae of NB4D2 strain by 2-DE. Int J Appl Agric Res 2009;4:125-30.

43. Shalaby NMM, Abd-Alla HI, Aly HF, Albalawy MA, Shaker KH, Bouajila J. Preliminary in vitro and in vivo evaluation of antidiabetic activity of Ducrosia anethifolia Boiss. and its linear furanocoumarins. Biomed Res Int 2014:1-13. http://dx.doi.org/10.1155/2014/480545

44. Matsumoto M, Hara H, Chiji H, Kasai T. Gastroprotective effect of red pigments in black chokeberry fruit (Aronia melanocarpa Elliot) on acute gastric hemorrhagic lesions in rats. J Agric Food Chem 2004;21:2226-9.

45. Dachicourt N, Bailbé D, Gangnerau MN, Serradas P, Ravel D, Portha B. Effect of gliclazide treatment on insulin secretion and beta-cell mass in noninsulin dependent diabetic Goto-kaki saki rats. Eur J Pharmacol 1998;361:243-51.

46. Villalba M, Martinez-Serrano A, Borner C, Blanco P, Satrustegui J. NMDA-induced increase in [Ca2+](i) and $45 \mathrm{Ca} 2+u p t a k e$ in acutely dissociated brain cells derived from adult rats. Brain Res 1992;570:347-53.

47. Deng Y, Xu ZF, Liu W, Xu B, Yang HB, Wei YG. Riluzole-triggered GSH synthesis via activation of glutamate transporters to antagonize methylmercury-induced oxidative stress in rat cerebral cortex. Oxid Med Cell Longevity 2012:1-12. Doi: $10.1155 / 2012 / 534705$

48. Ahmed HH, Shousha WG, Shalby AB, El-Mezayen HA, Ismaiel NN, Mahmoud NS. Implications of sex hormone receptor gene expression in the predominance of hepatocellular carcinoma in males: the role of natural products. Asian Pac J Cancer Prev 2014;16:4949-54.

49. Center SA. Metabolic, antioxidant, nutraceutical, probiotic, and herbal therapies relating to the management of hepatobiliary disorders. Vet Clin North Am Small Anim Pract 2004;34:67-172.

50. Nakamoto N, Kanai T. Role of toll-like receptors in immune activation and tolerance in the liver. Front Immunol 2014;5:1-8.

51. Samuni Y, Goldstein S, Dean OM, Berk M. The chemistry and biological activities of $\mathrm{N}$-acetylcysteine. Biochim Biophys Acta 2013;1830:4117-29.

52. Bhogal RH, Curbishley SM, Weston CJ, Adams DH, Afford SC. Reactive oxygen species mediate human hepatocyte injury during hypoxia/reoxygenation. Liver Transpl 2010;16:1303-13.

53. Czaja AJ. Hepatic inflammation and progressive liver fibrosis in chronic liver disease. World J Gastroenterol 2014;20:2515-32.

54. Lee HS. The pathogenic role of TGF- $\beta$ in diabetic nephropathy diabetes and metabolism. Int J Diabetes Metab 2013;S9:1-7.

55. Lee HS. Mechanisms and consequences of TGF- $\beta$ overexpression by podocytes in progressive podocyte disease. Cell Tissue Res 2012;347:129-40.

56. Mackness Mi, Durrington Pn, Mackness B. The role of paraoxonase 1 activity in cardiovascular disease: potential for therapeutic intervention. Am J Cardiovasc Drugs 2004;4:211-7.

57. Karabina Sa, Lehner An, Frank E, Parthasarathy S, Santanam N. Oxidative inactivation of paraoxonase-implications in diabetes mellitus and atherosclerosis. Biochim Biophys Acta 2005;1725:213-21.

58. Flekac M, Skrha J, Zidkova K, Lacinova Z, Hilgertova J. Paraoxonase 1 gene polymorphisms and enzyme activities in diabetes mellitus. Physiol Res 2008;57:717-26.

59. Kalousova M, Zima T, Tesarv, Dusilova-Sulkova S, Skrha J. Advanced glycoxidation end products in chronic diseases- 
clinical chemistry and genetic background. Mutat Res 2005;579:37-46.

60. Maritim Ac, Sanders Ra, Watkins Ib. Diabetes, oxidative stress, and antioxidants: a review. J Biochem Mol Toxicol 2003;17:24-38.

61. Saini KS, Thompson C, Winterford CM, Walker NI, Cameron DP. Streptozotocin at low doses induces apoptosis and at high doses causes necrosis in a murine pancreatic beta cell line, INS1. Biochem Mol Biol Int 1996;39:1229-36.

62. Turk J, Corbett JA, Romanadham S, Bohrer A, McDaniel ML. Biochemical evidence for nitric oxide formation from streptozotocin in isolated pancreatic islets. Biochem Biophys Res Commun 1993;197:1458-64.

63. Eizirik DL, Strandell E, Sandler S. Culture of mouse pancreatic islets in different glucose concentrations modifies B-cell sensitivity to streptozotocin. Diabetologia 1988;31:168-74.

64. Stennicke HR, Salvesen GS. Caspases-controlling intracellular signals by protease zymogen activation. Biochim Biophys Acta 2000;1477:299-306.

65. Maedler K, Spinas GA, Lehmann R, Sergeev P, Weber M, Fontana A, et al. Glucose induces beta-cell apoptosis via upregulation of the Fas receptor in human islets. Diabetes 2001;50:1683-90.

66. Soon YY, Tan BK. Evaluation of the hypoglycemic and antioxidant activities of Morinda officinalis in streptozotocininduced diabetic rats. Singapore Med J 2002;43:77-85.
67. Mak DH, Ip SP, Li PC, Poon MK, Ko KM. Alterations in tissue glutathione antioxidant system in streptozotocin-induced diabetic rats. Mol Cell Biochem 1996;162:153-8.

68. Williamson G, Clifford MN. Colonic metabolites of berry polyphenols: the missing link to biological activity? $\mathrm{Br} \mathrm{J}$ Nutr 2010;104:S48-66.

69. Pearson JR, Gill CI, Rowland IR. Diet, fecal water, and colon cancer development of a biomarker. Nutr Rev 2009;67:509-26.

70. Sharma M, Li L, Celver J, Killian C, Kovoor A, Seeram NP. Effects of fruit ellagitannin extracts, ellagic acid, and their colonic metabolite, urolithin A, on Wnt signaling. J Agric Food Chem 2010;58:3965-9.

71. Gonzalez-Sarrias A, Larrosa M, Tomas-Barberan FA, Dolara P, Espin JC. NF-kappa B-dependent anti-inflammatory activity of urolithins, gut microbiota ellagic acid-derived metabolites, in human colonic fibroblasts. Br J Nutr 2010;104:503-12.

\section{How to cite this article}

- $\quad$ Farouk K EL-Baz, Wagdy KB Khalil, Hanan F Aly, Hoda F Booles. Berry extracts improved inflammatory cytokines, antioxidant enzyme and suppressed the gene expression alterations in diabetic rats. Int J Pharm Pharm Sci 2016;8(11):294-302. 